\title{
Clinical and Preclinical Experience with Gefitinib and Sunitinib
}

\author{
Peter A. Fasching Michael P. Lux Claudia Rauh \\ Sebastian Jud Matthias W. Beckmann \\ Frauenklinik, Universitätsklinikum Erlangen, Germany
}

Key Words

Sunitnib - Gefitinib - Breast cancer - Tyrosine kinase . EGFR · VEGFR

\section{Summary}

Gefitinib and sunitinib are new targeted agents in cancer therapy. As a single-target agent gefitinib was one of the first tyrosine kinase inhibitors in solid cancers. It is an inhibitor of the intracellular domain of the epidermal growth factor receptor (EGFR). Most experience with this drug was made in the treatment of non-small cell lung cancer. Its efficacy in most other solid cancers is limited. Several studies could show an association between the response of non-small cell lung cancers to gefitinib and a mutation of the EGFR gene. This mutation changes the target and alters the sensitivity for the drug. In breast cancer limited data of phase II studies showed response rates lower than $2 \%$. Sunitinib as a multitarget agent inhibits several targets like vascular epidermal growth factor receptors (VEGFR) and other receptor tyrosine kinases. The efficacy of sunitinib against tumors is attributable to a direct antitumor activity and to an inhibition of neoangiogenesis. Most data exist for the treatment of metastatic renal cell carcinoma and gastrointestinal stromal tumors. Sunitinib could clearly improve the systemic treatment of these diseases. In the treatment of metastatic breast cancer response rates for the single agent therapy of $11 \%$ could be reported, which made this agent interesting for further phase III studies. These phase III studies are currently ongoing.

\author{
Schlüsselwörter \\ Sunitnib - Gefitinib - Mammakarzinom - Tyrosinkinase . \\ EGFR · VEGFR
}

\section{Zusammenfassung}

Gefitininb und Sunitinib sind neue Medikamente zur Krebstherapie. Sie inhibieren gezielt die intrazelluläre Tyrosinkinase-Domäne von Wachstumsfaktorrezeptoren. Gefitinib hat ein Ziel und inhibiert den Epidermal Growth Factor Receptor (EGFR). Die meisten Erfahrungen wurden beim nicht-kleinzelligen Lungenkarzinom gemacht. Die Wirksamkeit bei anderen soliden Tumoren ist begrenzt. Die Wirksamkeit bei Lungenkarzinomen konnte mit einer Mutation im EGFR-Gen assoziiert werden. Eine solche Mutation erhöht die Sensitivität der Lungenkarzinome für Gefitinib. Bei Patientinnen mit metastasiertem Mammakarzinom sind die Erfahrungen begrenzt. Die Ansprechraten bei vorbehandelten Patientinnen liegt unter $2 \%$. Sunitinib hat mehrere Ziele und inhibiert neben dem Vascular Epidermal Growth Factor Receptor (VEGFR) noch andere Wachstumsfaktorrezeptroren. Es wirkt nicht nur direkt zytostatisch sondern auch durch eine Inhibition der Neoangiogenese. Die meisten Daten gibt es zur Behandlung des Nierenzellkarzinoms und des gastrointestinalen Stromatumors. Hier konnte die systemische Behandlung durch Sunitinib entscheidend verbessert werden. Beim Mammakarzinom liegen die Ansprechraten für das metastasierte Mammakarzinom bei $11 \%$. Phase-III-Studien für das metastasierte Mammakarzinom sind gerade begonnen worden.

\begin{tabular}{ll}
\hline KARGER & @ 2007 S. Karger GmbH, Freiburg \\
Fax +497614520714 & Accessible online at: \\
$\begin{array}{l}\text { E-mail Information@Karger.de } \\
\text { www.karger.com }\end{array}$ & www.karger.com/brc
\end{tabular}

Dr. med. Peter A. Fasching

Universitätsklinikum Erlangen

Frauenklinik

Universitätsstraße 21-23, 91054 Erlangen, Germany

Tel. +49 9131 853-3508, Fax -3938

E-mail peter.fasching@gyn.imed.uni-erlangen.de 


\section{Introduction}

Gefitinib (Iressa ${ }^{\circledR}$, AstraZeneca, Wedel, Germany) and sunitinib (Sutent ${ }^{\circledR}$, Pfitzer Pharma GmbH, Karlsruhe, Germany) are two examples of receptor tyrosine kinase inhibitors (TKI) which differ in the development status and the number and kind of targeted receptor tyrosine kinases (RTK). This review focuses on the preclinical data, the clinical data and biological markers predicting the response or sensitivity.

\section{Gefitinib}

Gefitinib (fig. 1) is an orally active TKI, which blocks the epidermal growth factor receptor (EGFR) selectively. It has been tested in several solid cancer types, of which the results for non-small cell lung cancer (NSCLC) were most promising. Erlotinib (Tarceva ${ }^{\circledR}$, Roche Pharma AG, Grenzach-Whylen, Germany) is another drug, which is inhibiting the EGFR selectively and reversibly, but about that we will not report in this review. As an anilinoquinazoline agent, gefitinib has a highly specific affinity for EGFR. It prevents the dimerisation of the receptor with other human EGFRs and the autophosphorylation of the intracellular tyrosin kinase domain. This blocks the activation of downstream signaling, which includes the Ras/Raf/mitogen-activated protein kinase (MAPK) pathway, the phosphatidylinositol 3-kinase (PI3K/Akt) pathway and the signal transduction and activation of transcription (STAT) pathway. By blocking EGFR, gefitinib has an influence on cell growth, proliferation, signal transduction, activation of transcription and cell survival and apoptosis.

\section{Preclinical Data / Phase I Studies}

In preclinical models the cytostatic activity as a single agent or in combination with chemotherapeutic agents has been shown for several cancer cell line types and tumor xenografts like breast cancer, NSCLC, ovarian cancer, colon cancer, and prostate cancer $[1,2]$. Phase I studies were conducted with various cancer types, including breast, ovarian, colorectal, head and neck cancer and mostly NSCLC [3-7]. Dose limiting toxicity was reached at doses from $700 \mathrm{mg}$ /day to 1,000 $\mathrm{mg} /$ day. Side effects consisted mainly of diarrhea and skin rash. For further studies either a dose of $250 \mathrm{mg} /$ day or a dose of $500 \mathrm{mg} /$ day was chosen.

Treatment with gefitinib is predominantly associated with mild to moderate toxicities confined to the skin and gastrointestinal system. Skin toxicity consists mainly of pustular rash on an erythematous base. Gastrointestinal toxicity consists of loose or watery, intermittent, non-bloody, non-mucoid stools, occasionally with nausea or isolated episodes of emesis. There is no known hematopoietic, cardiovascular or renal toxicity. A total of 12 out of 282 patients with breast cancer were included in 5 phase I trials with gefinitnib. The response rate for the total of these pretreated patients with advanced disease
Fig. 1. Molecular structure of gefitinib.

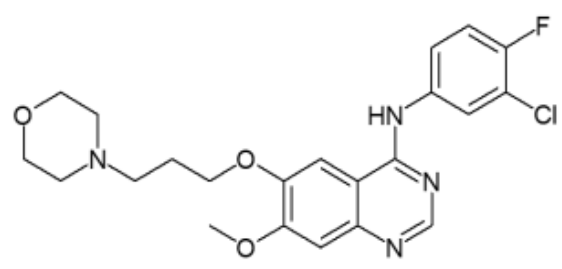

was $10 \%$ [8]. Data about the efficacy for breast cancer had to be obtained from further phase II studies.

\section{Phase II Studies}

Single agent therapy: A German study by von Minckwitz et al. [9], in which gefitinib was investigated in patients with metastatic breast cancer, who had a previous treatment with anthracyclines and taxanes, showed a response rate in $1,7 \%$ $(\mathrm{n}=58)$ of the patients with a dose of $500 \mathrm{mg} /$ day. The median time to progression (TTP) was 2.03 months. Most frequently reported toxicities in this cohort were diarrhea $(70,7 \%)$, dry skin $(27.6 \%)$, rash $(24,1 \%)$, nausea $(17.2 \%)$, exanthema (13.8\%) and fatigue (13.8\%) [9].

Another phase II study with 31 women treated metastatic breast cancer patients with a dose of $500 \mathrm{mg} /$ day [10]. No patient had a partial or complete response and 12 patients $38.7 \%$ had a stable disease. TTP was reported with 1.77 months. The largest phase II studies were performed with patients with NSCLC and colorectal cancer. The response rate in colorectal cancer patients was $<1 \%$ [11] and $9-19 \%$ in the NSCLC studies $[12,13]$.

Combination therapy: 33 metastatic breast cancer patients have been included into a phase II study with a combination treatment of gefitinib and trastuzumab [14]. Most of these patients $(\mathrm{n}=26)$ were chemotherapy naïve. 1 patient had a complete response and 6 achieved stable disease. TTP was 2.7 months.

Another trial investigated the combination of docetaxel $\left(75 \mathrm{mg} / \mathrm{m}^{2}\right)$ and gefitinib (250 mg per day) in 41 metastatic breast cancer patients as first-line treatment. $12 \%$ had a complete response and $42 \%$ a partial response.

In the neoadjuvant setting a combination of anastrozol and gefitinib was compared to gefitinib alone in a study with a prospective, randomized and double blind design [15]. These trials offer the opportunity not only to assess the response rate in treatment naïve patients but also to investigate the tumor sample regarding changes of biomarkers and to gain evidence about probable predictive markers for treatment success or to learn about the molecular treatment mechanisms. In this study 56 women were randomized. The primary objective was the inhibition of tumor cell proliferation, as measured by Ki67. One of further secondary objectives was the change of tumor size. The combination arm showed a significantly greater reduction of proliferation. The Ki67 labeling index was reduced by $92.4 \%$ in the gefitinib single treatment arm and by $98.0 \%$ in the combination arm with anastrozole. Tumor size reduc- 
Fig. 2. Molecular structure of sunitinib.

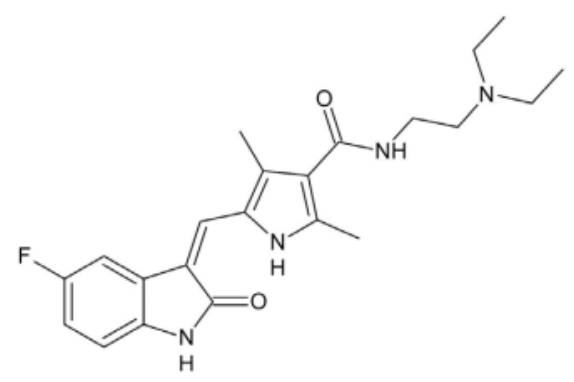

tion of $\geq 30 \%$ was achieved in 14 out of 28 patients with the combination treatment and in 12 of 22 patients receiving gefitinib alone.

\section{Phase III Data}

Due to the limited effect in phase II trials, no phase III trial with gefitinib was conducted. In advanced NSCLC 2 large controlled and prospectively randomized trials that added gefitinib to the standard chemotherapy could not prove an advantage in overall survival, which was the primary objective of these trials $[16,17]$

\section{Association of Biomarkers with Response}

In NSCLC patients (over)expression of EGFR and the gene mutation status of EGFR are discussed to be associated with the response to a treatment with gefitinib.

Concerning the expression of EGFR some studies could not find an association of EGFR expression by immunohistochemistry with the response to gefitinib $[18,19]$. Other studies, however, could associate a higher expression of EGFR with a longer survival and better response in patients who are treated with gefitinib [20] and erlotinib [21]. EGFR receptor expression may be a prognostic and a predictive factor. Evaluation of those mixed biomarkers may be difficult in a retrospective data set and bias the results [22]. Further studies are necessary to assess the prognostic and predictive value. Not much is known about biomarker associations in breast cancer patients. The one reported patient in the study of von Minckwitz et al. [9] had no (over) expression of EGFR.

On the genomic level an interesting observation has been made, which showed a major association of mutations in a part of the EGFR gene that could result in an altered ATP binding cleft of the intracellular tyrosine kinase domain. In May 2004 two working groups published associations between the response to gefitinib in lung cancer and the mutation status $[23,24]$. A mutation seems to enhance the effect of the tyrosine kinase inhibitor. The initial reports that almost all responders had such a mutation were adjusted by several studies, showing that a relevant proportion of mutation carriers can be refractory to treatment with EGFR inhibitors [25]. The advantage for mutation carriers, which was seen with regard to the response rate and time to progression, could not be shown concerning the overall survival [8].

\section{Conclusion}

Gefitinib was one of the first oral tyrosine kinase inhibitors used in the treatment of solid cancers. Treatment of NSCLC results in remarkable responses. However, the null results obtained from the large phase III studies and a low anticancer activity of gefitinib in other cancer types reflect on the changing paradigm in drug development. The proof of efficacy of targeted therapies is dependent on functional mechanisms that may be different from patient to patient. Trial designs without having good predictors of response endanger the scientists to conduct large trials in patient populations which a priori may be not suitable for those therapies.

\section{Sunitinib}

There is some evidence that the inhibition of EGFR results in a down regulation of the VEGFR signaling pathway and VEGFR blockade as well inhibits the autocrine signaling of EGFR [26-28]. Because of this interaction a synergistic effect of EGFR antagonists with anti-angiogenic agents like bevacizumab, which is a recombinant, humanized monoclonal antiVEGF antibody, was assumed. In a study combining erlotinib with bevacizumab in NSCLC a response rate of $20 \%$ and a median survival of 12.6 months [29] was observed. Another agent which blocks VEGFR and other RTK signaling is sunitinib (fig. 2).

Its antitumor activity was shown in several cancer types. It is approved for the treatment of advanced renal cell carcinoma and imatinib-resistant gastrointestinal stromal tumors (GIST). In phase I, II and III studies more than 4,000 patients received the drug up to now. Sorafenib is a further multitarget TKI, which has been approved in the United States. These multitarget TKI are recently in the focus of interest, because they inhibit several related pathways and may achieve a better efficacy in a broader spectrum of tumors than single target TKI.

By inhibiting several targets, the efficacy of sunitinib against tumors is attributable to a direct antitumor activity and to an inhibition of neoangiogenesis. As well in solid cancers as in hematological malignancies additional receptor tyrosine kinases (RTK) other than the ones from the HER family are implicated in tumor growth and survival of cancer cells. These RTK include vascular endothelial growth factor receptor 1, 2 and 3 (VEGFR), platelet derived growth factor receptors $\alpha$ and $\beta$ (PDGFR), the stem cell factor receptor (SCFR or KIT) and FMS-related tyrosine kinase 3-ligand receptor (FLT3R) [30-32].

\section{Preclinical Data and Phase I Studies}

Dose finding studies have been performed as single and multiple dose studies with a range from $25 \mathrm{mg} / \mathrm{d}$ to $100 \mathrm{mg} / \mathrm{d}$. Most of the studies started with a dose of $50 \mathrm{mg} / \mathrm{d}$ for 4 weeks followed by an interruption of medication for 2 weeks. The most common toxicities included gastrointestinal effects like diar- 
rhea, nausea, stomatitis and dyspepsia, myelosuppresion including neutropenia and thrombocytopenia, dermatological disorders like dermatitis, alterations of skin, especially handfoot-syndrome, skin and hair depigmentation. Furthermore fatigue and asthenia have been observed.

\section{Phase II Data}

The cancer types which were mostly investigated with sunitinib are renal cell carcinoma (RCC), GIST and acute myelogenous leukemia (AML).

Renal cell carcinoma: In RCC chemotherapy response rates to common therapies rarely exceed $6 \%$ and response rates to interleukin and interferon are about $10-15 \%$ [33-36]. 2 phase II studies revealed promising response rates of $40 \%$ and $39 \%$ for the single agent therapy with sunitinib [37, 38].

Gastrointestinal stromal tumors: GIST are the most common sarcoma of the gastrointestinal tract and account for $0.2 \%$ of all gastrointestinal malignancies [39]. The median survival for patients who cannot be treated sufficiently by surgery or are metastatic is only 10-23 months [40] and the response rate to chemotherapy for these tumors is poor [40]. With partial responses of about $54 \%$ and stable diseases in about $28 \%$ of the patients the treatment with imatinib improved the treatment options clearly [41] and it was approved for the treatment of metastatic and non-resectable GIST in February 2001. The treatment effect is assumed to be associated with mutations of the KIT proto-oncogene which can be found in the majority of GIST [42] as well as activating mutations of the PDGFR- $\alpha$ [43].

For the treatment of imatinib-resistant GIST a phase I/II trial showed encouraging clinical activity [44]. The clinical benefit of sunitinib in this trial could be associated with secondary KIT mutations in exon 13 or 14 , which was $65 \%$ in this subgroup of patients.

Breast cancer: In a single arm, open labeled phase II study 64 patients have been treated with $50 \mathrm{mg}$ sunitinib per day for 4 weeks followed by an interruption of treatment for 2 weeks. The patients have been previously treated with anthracyclines and taxanes. 7 patients (11\%) had an objective response and 3 patients $(5 \%)$ had a stable disease which lasted longer than 6 months [45]. In this patient group neutropenia was more common than in previous studies. However, the neutrophil rebound was rapid after treatment rest and there were no cases of neutropenic fever. Other adverse events were as frequent as expected. In order to identify biomarkers which correlate with response, plasma levels of soluble proteins have been analyzed in this trial. Besides changes of VEGF and soluble VEGFR2 and VEGFR3 changes of soluble KIT have been observed. Decreases of soluble KIT $>50 \%$ by the end of cycle 2 were correlated with significantly better treatment outcomes for time-to-progression and survival [46].
Another multinational phase II study which is recruiting in Germany as well, is a randomized trial comparing sunitinib in anthracylin and taxan resistant patients versus a standard of care single chemotherapy regimen. This trial is addressing the subgroup of triple negative (HER2, estrogen and progesterone receptor negative) breast cancer patients (http://clinicaltrials.gov/show/NCT00246571).

\section{Phase III Data}

For metastatic $R C C$ a prospectively randomized trial compared a treatment with sunitinib versus a medication with interferon-alpha (IFN- $\alpha)$. It demonstrated a significant improvement in progression free survival and a superior objective response rate for sunitinib over IFN- $\alpha$ [47]. The median progression free survival was almost doubled (24.9 weeks for IFN and 47.3 weeks for sunitinib) and the objective response rate in the sunitinib arm was $24.8 \%$ compared to $4.9 \%$ in the interferon arm. In breast cancer several phase III trials have been conducted recently.

In imatinib-resistant GIST patients a prospectively randomized, double blinded phase III trial compared a treatment with sunitinib versus a placebo treatment. 207 patients received sunitinib and 105 patients were randomized into the placebo arm [48]. This trial had to be unblinded early because an interim analysis revealed a clear advantage in favor of sunitinib. Patients in the sunitinib arm had a time to progression of 27,3 months and patients in the placebo arm 6,4 months $(\mathrm{p}<0.0001)$. The interim analysis of this phase III trial was part of the FDA approval of sunitinib in January 2006.

The data in breast cancer are limited. One study is comparing the treatment of metastatic breast cancer with docetaxel versus a combination of docetaxel and sunitinib (http://clinicaltrials.gov/show/NCT00393939). Another clinical investigation compares sunitinib plus paclitaxel versus bevacizumab plus paclitaxel in patients with advanced breast cancer (http://clinicaltrials.gov/ct/show/NCT00373256). Capacetabine as a single agent treatment for patients with metastatic breast cancer after an anthracycline and taxane treatment is compared to sunitinib as a single agent treatment in a phase III study, which is about to enroll more than 700 patients (http://clinicaltrials.gov/show/NCT00373113). Further phase III studies comparing combinations of sunitinib with cytostatic agents versus chemotherapy alone are planed.

\section{Conclusion}

Sunitinib is a well tolerated multitarget TKI with a favorable toxicity profile. It is established in the treatment of metastatic renal cell carcinoma and the treatment of gastrointestinal stromal tumors. For further malignancies like breast cancer promising data of phase II studies have been published. Results of large phase III trials are still pending as these trials have recently been conducted. 


\section{References}

1 Ciardiello F, Caputo R, Bianco R, Damiano V, Pomatico G, De Placido S, Bianco AR, Tortora G: Antitumor effect and potentiation of cytotoxic drugs activity in human cancer cells by ZD-1839 (Iressa), an epidermal growth factor receptor-selective tyrosine kinase inhibitor. Clin Cancer Res 2000;6:2053-2063.

2 Sirotnak FM: Studies with ZD1839 in preclinical models. Semin Oncol 2003;30:12-20.

3 Ranson M, Hammond LA, Ferry D, Kris M, Tullo A, Murray PI, Miller V, Averbuch S, Ochs J, Morris C, Feyereislova A, Swaisland H, Rowinsky EK: ZD1839, a selective oral epidermal growth factor receptor-tyrosine kinase inhibitor, is well tolerated and active in patients with solid, malignant tumors: results of a phase I trial. J Clin Oncol 2002;20: 2240-2250.

4 Nakagawa K, Tamura T, Negoro S, Kudoh S, Yamamoto N, Takeda K, Swaisland H, Nakatani I, Hirose M, Dong RP, Fukuoka M: Phase I pharmacokinetic trial of the selective oral epidermal growth factor receptor tyrosine kinase inhibitor gefitinib ('Iressa', ZD1839) in Japanese patients with solid malignant tumors. Ann Oncol 2003;14:922-930.

$\checkmark 5$ Herbst RS, Maddox AM, Rothenberg ML, Small EJ, Rubin EH, Baselga J, Rojo F, Hong WK, Swaisland H, Averbuch SD, Ochs J, LoRusso PM: Selective oral epidermal growth factor receptor tyrosine kinase inhibitor ZD1839 is generally well-tolerated and has activity in non-small-cell lung cancer and other solid tumors: results of a phase I trial. J Clin Oncol 2002;20:3815-3825.

6 Baselga J: Targeting the epidermal growth factor receptor with tyrosine kinase inhibitors: small molecules, big hopes. J Clin Oncol 2002;20:2217-2219.

7 Goss G, Hirte H, Miller WH, Jr:, Lorimer IA, Stewart D, Batist G, Parolin DA, Hanna P, Stafford S, Friedmann J, Walsh W, Mathews S, Douglas L, Seymour LK: A phase I study of oral ZD 1839 given daily in patients with solid tumors: IND.122, a study of the Investigational New Drug Program of the National Cancer Institute of Canada Clinical Trials Group. Invest New Drugs 2005;23:147-155.

8 Cappuzzo F, Finocchiaro G, Metro G, Bartolini S, Magrini E, Cancellieri A, Trisolini R, Castaldini L, Tallini G, Crino L: Clinical experience with gefitinib: an update. Crit Rev Oncol Hematol 2006;58: $31-45$.

$\checkmark$ von Minckwitz G, Jonat W, Fasching P, du Bois A, Kleeberg U, Luck HJ, Kettner E, Hilfrich J, Eiermann W, Torode J, Schneeweiss A: A multicentre phase II study on gefitinib in taxane- and anthracycline-pretreated metastatic breast cancer. Breast Cancer Res Treat 2005;89:165-172.

10 Baselga J, Albanell J, Ruiz A, Lluch A, Gascon P, Guillem V, Gonzalez S, Sauleda S, Marimon I, Tabernero JM, Koehler MT, Rojo F: Phase II and tumor pharmacodynamic study of gefitinib in patients with advanced breast cancer. J Clin Oncol 2005;23:5323-5333.

11 Rothenberg ML, LaFleur B, Levy DE, Washington MK, Morgan-Meadows SL, Ramanathan RK, Berlin JD, Benson AB, 3rd, Coffey RJ: Randomized phase II trial of the clinical and biological effects of two dose levels of gefitinib in patients with recurrent colorectal adenocarcinoma. J Clin Oncol 2005;23:9265-9274.
12 Fukuoka M, Yano S, Giaccone G, Tamura T, Nakagawa K, Douillard JY, Nishiwaki Y, Vansteenkiste J, Kudoh S, Rischin D, Eek R, Horai T, Noda K, Takata I, Smit E, Averbuch S, Macleod A, Feyereislova A, Dong RP, Baselga J: Multi-institutional randomized phase II trial of gefitinib for previously treated patients with advanced non-small-cell lung cancer (The IDEAL 1 Trial) [corrected]. J Clin Oncol 2003;21:2237-2246.

13 Kris MG, Natale RB, Herbst RS, Lynch TJ, Jr., Prager D, Belani CP, Schiller JH, Kelly K, Spiridonidis H, Sandler A, Albain KS, Cella D, Wolf MK, Averbuch SD, Ochs JJ, Kay AC: Efficacy of gefitinib, an inhibitor of the epidermal growth factor receptor tyrosine kinase, in symptomatic patients with non-small cell lung cancer: a randomized trial. Jama 2003;290:2149-2158.

14 Arteaga CL, O'Neil A, Moulder SL, Pins M, Sparano JA, Sledge GW, Davidson NE, Boston MA: ECOG1100: a phase I-II study of combined blockade of the erbB receptor network with trastuumab and gefitinib ('Iressa') in patients (pts) with HER2overexpressing metastatic breast cancer (met br ca). Breast Cancer Res Treat 2004;88:S15.

15 Polychronis A, Sinnett HD, Hadjiminas D, Singhal H, Mansi JL, Shivapatham D, Shousha S, Jiang J, Peston D, Barrett N, Vigushin D, Morrison K, Beresford E, Ali S, Slade MJ, Coombes RC: Preoperative gefitinib versus gefitinib and anastrozole in postmenopausal patients with oestrogen-receptor positive and epidermal-growth-factor-receptor-positive primary breast cancer: a double-blind placebo-controlled phase II randomised trial. Lancet Oncol 2005;6:383-391.

16 Giaccone G, Herbst RS, Manegold C, Scagliotti G, Rosell R, Miller V, Natale RB, Schiller JH, Von Pawel J, Pluzanska A, Gatzemeier U, Grous J, Ochs JS, Averbuch SD, Wolf MK, Rennie P, Fandi A, Johnson DH: Gefitinib in combination with gemcitabine and cisplatin in advanced non-small-cell lung cancer: a phase III trial-INTACT 1. J Clin Oncol 2004:22:777-784.

17 Herbst RS, Giaccone G, Schiller JH, Natale RB, Miller V, Manegold C, Scagliotti G, Rosell R, Oliff I, Reeves JA, Wolf MK, Krebs AD, Averbuch SD, Ochs JS, Grous J, Fandi A, Johnson DH: Gefitinib in combination with paclitaxel and carboplatin in advanced non-small-cell lung cancer: a phase III trial-INTACT 2. J Clin Oncol 2004;22:785-794.

18 Bailey R, Kris M, Wolf M, Kay A, Averbuch S, Askaa J, Janas M, Schmidt K, Fukuoka M: Gefitinib (Iressa, ZD 1839) monotherapy for pretreated advanced non-small cell lung cancer in IDEAL 1 and 2: tumor response is not clinically relevantly predictable from tumor EGFR membrane staining aloneLung Cancer 2003, 41:s71. Lung Cancer 2003; 41:S71.

19 Cappuzzo F, Gregorc V, Rossi E, Cancellieri A, Magrini E, Paties CT, Ceresoli G, Lombardo L, Bartolini S, Calandri C, de Rosa M, Villa E, Crino L: Gefitinib in pretreated non-small-cell lung cancer (NSCLC): analysis of efficacy and correlation with HER2 and epidermal growth factor receptor expression in locally advanced or metastatic NSCLC. J Clin Oncol 2003;21:2658-2663.
20 Cappuzzo F, Hirsch FR, Rossi E, Bartolini S Ceresoli GL, Bemis L, Haney J, Witta S, Danenberg K, Domenichini I, Ludovini V, Magrini E, Gregorc V, Doglioni C, Sidoni A, Tonato M, Franklin WA, Crino L, Bunn PA, Jr., Varella-Garcia M: Epidermal growth factor receptor gene and protein and gefitinib sensitivity in non-small-cel lung cancer. J Natl Cancer Inst 2005;97:643-655.

21 Tsao MS, Sakurada A, Cutz JC, Zhu CQ, KamelReid S, Squire J, Lorimer I, Zhang T, Liu N, Daneshmand M, Marrano P, da Cunha Santos G, Lagarde A, Richardson F, Seymour L, Whitehead M, Ding K, Pater J, Shepherd FA: Erlotinib in lung cancer - molecular and clinical predictors of outcome. N Engl J Med 2005;353:133-144.

22 Fasching PA, Lux MP, Beckmann K, Strick R, Beckmann MW: Prognose- und Prädiktivfaktoren - Entscheidungshilfen bei der Therapiewahl für Patientinnen mit Mammakarzinom. Gynäkologe 2005;38:388-397.

23 Lynch TJ, Bell DW, Sordella R, Gurubhagavatula S, Okimoto RA, Brannigan BW, Harris PL, Haserlat SM, Supko JG, Haluska FG, Louis DN, Christiani DC, Settleman J, Haber DA: Activating mutations in the epidermal growth factor receptor underlying responsiveness of non-small-cell lung cancer to gefitinib. N Engl J Med 2004;350:2129-2139.

24 Paez JG, Janne PA, Lee JC, Tracy S, Greulich H, Gabriel S, Herman P, Kaye FJ, Lindeman N, Boggon TJ, Naoki K, Sasaki H, Fujii Y, Eck MJ, Sellers WR, Johnson BE, Meyerson M: EGFR mutations in lung cancer: correlation with clinical response to gefitinib therapy. Science 2004;304:1497-1500.

25 Shigematsu H, Lin L, Takahashi T, Nomura M, Suzuki M, Wistuba, II, Fong KM, Lee H, Toyooka S, Shimizu N, Fujisawa T, Feng Z, Roth JA, Herz J, Minna JD, Gazdar AF: Clinical and biological features associated with epidermal growth factor receptor gene mutations in lung cancers. J Natl Cancer Inst 2005;97:339-346.

26 de Jong JS, van Diest PJ, van der Valk P, Baak JP. Expression of growth factors, growth-inhibiting factors, and their receptors in invasive breast cancer. II: Correlations with proliferation and angiogenesis. J Pathol 1998;184:53-57.

27 Petit AM, Rak J, Hung MC, Rockwell P, Goldstein N, Fendly B, Kerbel RS: Neutralizing antibodies against epidermal growth factor and ErbB-2/neu receptor tyrosine kinases down-regulate vascula endothelial growth factor production by tumor cells in vitro and in vivo: angiogenic implications for signal transduction therapy of solid tumors. Am J Pathol 1997;151:1523-1530.

28 Hirata A, Ogawa S, Kometani T, Kuwano T, Naito S, Kuwano M, Ono M: ZD1839 (Iressa) induces antiangiogenic effects through inhibition of epidermal growth factor receptor tyrosine kinase. Cancer Res 2002;62:2554-2560.

29 Herbst RS, Johnson DH, Mininberg E, Carbone DP, Henderson T, Kim ES, Blumenschein G, Jr. Lee JJ, Liu DD, Truong MT, Hong WK, Tran H, Tsao A, Xie D, Ramies DA, Mass R, Seshagiri S Eberhard DA, Kelley SK, Sandler A: Phase I/II trial evaluating the anti-vascular endothelial growth factor monoclonal antibody bevacizumab in combination with the HER-1/epidermal growth factor receptor tyrosine kinase inhibitor erlotinib for patients with recurrent non-small-cell lung cancer. J Clin Oncol 2005;23:2544-2555. 
\$3 Abrams TJ, Lee LB, Murray LJ, Pryer NK, Cherrington JM: SU11248 inhibits KIT and platelet-derived growth factor receptor beta in preclinical models of human small cell lung cancer. Mol Cancer Ther 2003;2:471-478.

\31 O'Farrell AM, Foran JM, Fiedler W, Serve H, Paquette RL, Cooper MA, Yuen HA, Louie SG, Kim $\mathrm{H}$, Nicholas S, Heinrich MC, Berdel WE, Bello C, Jacobs M, Scigalla P, Manning WC, Kelsey S, Cherrington JM: An innovative phase I clinical study demonstrates inhibition of FLT3 phosphorylation by SU11248 in acute myeloid leukemia patients. Clin Cancer Res 2003;9:5465-5476.

32 Mendel DB, Laird AD, Xin X, Louie SG, Christensen JG, Li G, Schreck RE, Abrams TJ, Ngai TJ, Lee LB, Murray LJ, Carver J, Chan E, Moss KG, Haznedar JO, Sukbuntherng J, Blake RA, Sun L, Tang C, Miller T, Shirazian S, McMahon G, Cherrington JM: In vivo antitumor activity of SU11248, a novel tyrosine kinase inhibitor targeting vascular endothelial growth factor and platelet-derived growth factor receptors: determination of a pharmacokinetic/pharmacodynamic relationship. Clin Cancer Res 2003;9:327-337.

33 Yagoda A, Abi-Rached B, Petrylak D: Chemotherapy for advanced renal-cell carcinoma: 1983-1993. Semin Oncol 1995;22:42-60.

34 Rosenberg SA, Yang JC, Topalian SL, Schwartzentruber DJ, Weber JS, Parkinson DR, Seipp CA, Einhorn JH, White DE: Treatment of 283 consecutive patients with metastatic melanoma or renal cell cancer using high-dose bolus interleukin 2. Jama 1994;271:907-913.

- 35 Kerst JM, Bex A, Mallo H, Dewit L, Haanen JB, Boogerd W, Teertstra HJ, de Gast GC: Prolonged low dose IL-2 and thalidomide in progressive metastatic renal cell carcinoma with concurrent radiotherapy to bone and/or soft tissue metastasis: a phase II study. Cancer Immunol Immunother 2005; 54:926-931.

-36 Bex A, Mallo H, Kerst M, Haanen J, Horenblas S, de Gast GC: A phase-II study of pegylated interferon alfa-2b for patients with metastatic renal cell carcinoma and removal of the primary tumor. Cancer Immunol Immunother 2005;54:713-719.
37 Motzer RJ, Rini BI, Bukowski RM, Curti BD, George DJ, Hudes GR, Redman BG, Margolin KA, Merchan JR, Wilding G, Ginsberg MS, Bacik J, Kim ST, Baum CM, Michaelson MD: Sunitinib in patients with metastatic renal cell carcinoma. Jama 2006;295:2516-2524.

38 Motzer RJ, Michaelson MD, Redman BG, Hudes GR, Wilding G, Figlin RA, Ginsberg MS, Kim ST, Baum CM, DePrimo SE, Li JZ, Bello CL, Theuer CP, George DJ, Rini BI: Activity of SU11248, a multitargeted inhibitor of vascular endothelial growth factor receptor and platelet-derived growth factor receptor, in patients with metastatic renal cell carcinoma. J Clin Oncol 2006;24:16-24.

39 Fletcher CD, Berman JJ, Corless C, Gorstein F, Lasota J, Longley BJ, Miettinen M, O'Leary TJ, Remotti H, Rubin BP, Shmookler B, Sobin LH, Weiss SW: Diagnosis of gastrointestinal stromal tumors: A consensus approach. Hum Pathol 2002;33: 459-465.

40 Ratain MJ, Eisen T, Stadler WM, Flaherty KT, Kaye SB, Rosner GL, Gore M, Desai AA, Patnaik A, Xiong HQ, Rowinsky E, Abbruzzese JL, Xia C, Simantov R, Schwartz B, O'Dwyer PJ: Phase II placebo-controlled randomized discontinuation trial of sorafenib in patients with metastatic renal cell carcinoma. J Clin Oncol 2006;24:2505-2512.

41 Demetri GD, von Mehren M, Blanke CD, Van den Abbeele AD, Eisenberg B, Roberts PJ, Heinrich MC, Tuveson DA, Singer S, Janicek M, Fletcher JA, Silverman SG, Silberman SL, Capdeville R, Kiese B, Peng B, Dimitrijevic S, Druker BJ, Corless C, Fletcher CD, Joensuu H: Efficacy and safety of imatinib mesylate in advanced gastrointestinal stromal tumors. N Engl J Med 2002;347:472-480.

42 Hirota S, Isozaki K, Moriyama Y, Hashimoto K, Nishida T, Ishiguro S, Kawano K, Hanada M, Kurata A, Takeda M, Muhammad Tunio G, Matsuzawa Y, Kanakura Y, Shinomura Y, Kitamura Y: Gainof-function mutations of c-kit in human gastrointestinal stromal tumors. Science 1998;279:577-580.

43 Heinrich MC, Corless CL, Duensing A, McGreevey L, Chen CJ, Joseph N, Singer S, Griffith DJ, Haley A, Town A, Demetri GD, Fletcher CD, Fletcher JA: PDGFRA activating mutations in gastrointestinal stromal tumors. Science 2003;299: 708-710.
44 Heinrich MC, Maki RG, Corless CL, Antonescu CR, Fletcher JA, Fletcher CD, Huang X, Baum CM, Demetri GD: Sunitinib (SU) response in imatinib-resistant (IM-R) GIST correlates with KIT and PDGFRA mutation status. J Clin Oncol 2006; 2006 ASCO Annual Meeting Proceedings Part I. Vol 24, No. 18S (June 20 Supplement):9502.

45 Miller KD, Burstein HJ, Elias AD, Rugo HS, Cobleigh MA, Pegram MD, Eisenberg PD, Collier M, Adams BJ, Baum CM: Phase II study of SU11248, a multitargeted receptor tyrosine kinase inhibitor (TKI), in patients (pts) with previously treated metastatic breast cancer (MBC). J Clin Oncol 2005;2005 ASCO Annual Meeting Proceedings. Vol 23, No. 16S, Part I of II:563.

46 Deprimo SE, Friece C, Huang X, Smeraglia J, Sherman L, Collier M, Baum C, Elias AD, Burstein HJ, Miller KD: Effect of treatment with sunitinib malate, a multitargeted tyrosine kinase inhibitor, on circulating plasma levels of VEGF, soluble VEGF receptors 2 and 3, and soluble KIT in patients with metastatic breast cancer. J Clin Oncol 2006;2006 ASCO Annual Meeting Proceedings Part I. Vol 24, No. 18S:578.

47 Motzer RJ, Hutson TE, Tomczak P, Michaelson MD, Bukowski RM, Rixe O, Oudard S, Kim ST, Baum CM, Figlin RA: Phase III randomized trial of sunitinib malate (SU11248) versus interferonalfa (IFN-a) as first-line systemic therapy for patients with metastatic renal cell carcinoma (mRCC). J Clin Oncol, 2006 ASCO Annual Meeting Proceedings Part I 2006;24:LBA3.

48 Demetri GD, van Oosterom AT, Garrett CR, Blackstein ME, Shah MH, Verweij J, McArthur G, Judson IR, Heinrich MC, Morgan JA, Desai J, Fletcher CD, George S, Bello CL, Huang X, Baum $\mathrm{CM}$, Casali PG: Efficacy and safety of sunitinib in patients with advanced gastrointestinal stromal tumour after failure of imatinib: a randomised controlled trial. Lancet 2006:368:1329-1338. 